\title{
Critiquing Economic Values in English Language Teaching: Materials Problems and Critical Solutions Facing Teachers
}

Neil Addison

\begin{abstract}
This paper contends that the English language teaching industry is implicitly imbued with Western cultural values which, whilst emanating from the ideological discourse of colonialism, have now evolved into an aggressive corporate colonialism. An examination of various materials employed in ELT finds that they are saturated with market driven Western values and product placements, which, if not explicated properly, can confuse students who may come from very different schematic backgrounds (Widdowson, 1990). A more critical classroom approach is therefore advocated, where foreign English language students are encouraged to use vocabulary to critique cultural contents encountered in ELT materials, affording them the chance to engage with English more dynamically. A 2012 teaching approach is described, which sought to achieve this aim within the context of a Japanese university English conversation class. The effectiveness of this approach is then assessed and discussed through the examination of quantitative and qualitative student response data.
\end{abstract}

Key Words: ELT; Colonialism; Globalization; Textbooks; Cultural criticism

\section{Introduction}

Much has been written about the different relationships between English language teaching and learning in varying pedagogic contexts, and about the different problems, and resulting approaches which individual teachers have to consider. One pedagogic factor which is non-context specific, however, concerns the fact that Western culture permeates the ELT industry, from economic rationale to textbook design and classroom practice, ensuring that materials are often saturated with market driven values and product placements (Litz, 2002, p.6).

The ELT industry is empowered by the economic superiority of the United States and the United Kingdom, resulting in an unequal situation where the opportunities for realizing "the functional potential of English on the Japanese market are far better than those of realizing the functional potential of Japanese on the American market" (Coulmas, 1992, p.67), leading many to argue that native speakers of English have used their language to exercise 
hegemonic domination through "economic, cultural and commercial globalization" (Howatt \& Widdowson, 2004, p.359). Examples of this economic domination include organizations such as the British Council (Phillipson, 1992, p.48) and Educational Testing Service (ETS), the US based administrator of Test of English for International Communication (TOEIC) and Test of English as a Foreign Language (TOEFL) (Oh \& Kang, 2009), which have been accused of exploiting English for economic purposes. In addition, the contents of some ELT materials, such as textbooks, have been accused of aiding the practises of Western corporations, legitimizing global brands and products as an inevitable norm (Gray, 2010). Due to this, some teaching practitioners have expressed a reluctance to use ELT materials (Sell, 2005, p.86), whilst others advocate engaging with the culture in them more dynamically, to achieve a much deeper level of communicative competence and fluency (Kramsch, 1993).

This paper therefore seeks to examine the problematic economic values which direct and shape the ELT industry, and to discuss the role of materials such as textbooks in the classroom, before arguing in favor of English teachers introducing a more critical pedagogical approach when engaging with such materials. Finally, the effectiveness of a 2012 teaching approach, which sought to achieve this aim within the context of a Japanese university English conversation class, is described, assessed and discussed. Before discussing ELT materials, and how best to approach them critically in English classes, however, it is first necessary to foreground the exploitative background which underpins the ELT industry, which is in turn subtly shaped by the historical ideology of colonialism.

\section{ELT and colonialist discourses}

ELT can be seen to promote values historically connected with colonialism (Phillipson, 1992, p.75), as the commercial exploitation of the English language has a long and honourable history (Howatt\& Widdowson, 2004, p.357), exemplified by the British Council's 1983 admission of "exploiting English" (Phillipson, 1992, p.144) through enforcing cultural values. Colonialist values presupposed that there were large swathes of terra incognita waiting to be discovered and mapped by 'civilization'; this ideology is still echoed in ELT textbooks, such as Headway UpperIntermediate, which includes a reading feature on the explorer Marco Polo's 'discovery' of China, then juxtaposing this with another reading exercise featuring a Western backpacker exploring the Far East (Soars \& Soars, 2005, p.16). This ethnocentric depiction of an adventurous Westerner discovering the world is therefore brought from the past into the present. However, this adventure seeking attitude may implicitly influence the motivation of many Westerners working abroad as English teachers. Their motivation for teaching may not be commensurate with the requirements of their learners, whilst they may not possess the required pedagogic skills. Griffith notes the "proliferation of cowboy teachers who 
have no feel for language, no interest in their pupils and no qualms about ripping them off" (1999, p.11). Even skilled language teachers, however, may not properly understand the foreign pedagogic systems in which they are employed, and may mistakenly apply Western solutions to distinctly non-Western problems. Tollefson argues that "ESL experts are often hired as consultants to disperse 'solutions' to complex educational problems in countries about which they know very little" (1991, p.97). This is comparable to the ideology displayed in the title of the teaching handbook Teaching English Abroad: Talk Your Way Around the World (Griffith, 1999), in which the emphasis is placed on talking rather than listening, or learning. ELT can be seen as a top down, colonial exercise which dispenses knowledge and values whilst establishing a disconnection "from the social context within which it operates" (Phillipson, 1992, p.259).

\section{ELT and globalization}

Whilst some contend that the colonial age has ceased to exist, others see the economic processes of globalization as a continuation of the same ongoing historical project (Goldsmith, 2001, p.19). The beginning of this modern corporate colonialism can arguably be traced back to the 1973 Organization of the Petroleum Exporting Countries (OPEC) oil crisis, which ushered in a historical sea change within the world of macroeconomics, leading to a collapse of the Bretton Woods economic system and a subsequent rejection of Keysian economics. The rise to prominence of
Western laissez-faire economics precipitated a shift in English language teaching policy towards the newer oil based economic system (Brumfit, 2001, p.118), overseeing "a period of change which radically altered the scope and structure of ELT" (Howatt \& Widdowson, 2004, p.232).In this neoeconomic world, English became a valuable commodity analogous to oil, exemplified by the British Council's $1987 / 88$ report which specifically identified that "Britain's real black gold is not North Sea Oil but the English language" (Phillipson, 1992, p.48). For the Council, the challenge regarding English was thus to "exploit it to the full" (1992, p.48).

This has led to the Council prioritizing the opening of offices in highly lucrative markets such as China and the Gulf, whilst closing a number of offices in countries judged of little economic importance. The closure of the Belarus office invited Parliamentary criticism in 2001, prompting the Minister for Europe, Peter Hain, to respond by informing the House of Commons that "the decision to close the British Council operation in Minsk followed a strategic review by the council designed to maximize effectiveness world wide" (Parliament UK, 2001). This statement underlines the primary interest of the council, which one understands in this context as being the pursuit of economic gain through exploiting the commodity value of English. Companies in the United States have also been accused of exploiting English for economic purposes. US based ETS, the administrator of TOEIC and TOEFL, which administers English tests in more than 180 countries worldwide, 
(ETS, 2013) has been accused of failing to pay taxes in Korea on tests which cost 25 billion won in annual fees (Oh \& Kang, 2009). This is despite the findings of a 2008 Korean policy paper, which found that the high dependency on foreign English proficiency tests means 23 billion won...flowing out of Korea each year (Kim, 2012).

By employing an imperialist theoretical framework one can pursue the argument that globalization is a continuation of the same discourses that colonialism created (Mar-Molinero, 2006, p.78).Whilst colonial powers have historically exported Western cultural values, in the neo-economic global world Western businesses now export corporate values. Concern has been raised that this economic process will ensure an increasingly Western influenced global homogenization, driven by consolidated corporate interests. Integrated marketing strategies ensure that Disney products and imagery promote McDonalds, which it has a 'tie-in' with, whilst Warner Bros is joined with Burger King (Pilger, 1999, p.69). Others argue that the entire educational sector is pervaded by the business ideology of powerful multinational companies. Bello (2001) claims that brand names such as "CocaCola, Pepsi, McDonalds, Burger King and Proctor \& Gamble are also directly involved in developing curricula for schools along with advertising promotions to help kids grow up corporate" (p.133). The ELT industry has also been criticized for promoting Western corporate interests (Gray, 2010, p.729), and for depending on "the capitalizing interests and exploitations of the sponsoring agent" (Litz, 2002, p.6).
Recent textbooks such as Headway Upper-Intermediate and English File Upper Intermediate have committed acts of product placement, containing articles on Western corporations such as Starbucks (Soars \& Soars, 2005, p.58), and McDonalds (Oxenden\&Latham-Koenig, 2001, p.108).

\section{ELT materials content}

The content of ELT textbooks serves to aid the practises of Western corporations, legitimizing global brands and products as an inevitable norm. English File Upper-Intermediate refers to McDonalds as having "fundamentally changed human behaviour in every country" (Oxenden \& Latham-Koenig, 2001, p.108), and English language students are encouraged to believe in the legitimacy of this, and are tacitly led to consider themselves, for good or ill, as having been "McColonized" (2001, p.108). Similarly, Cutting Edge PreIntermediate features a gap fill exercise which requires students to add verb forms to an incomplete passage of text featuring Nike shoes (Cunningham, Moor \& Comyns-Carr, 2005, p.109), and New Headway Elementary contains a gap fill activity which centres on Coca Cola and Wranglers jeans (Soars\& Soars, 2012, p.60). ELT textbooks can be understood as serving to pave the ground for the development of markets favorable to Western interests, where "the timely provision of ELT textbooks was identified as a strategic initial move" (Gray, 2010, p.716). ELT textbooks thus legitimize economic and vocational roles in a neo-liberal climate where individuals are encouraged to 
brand themselves to stand out. Textbooks accentuate this process by featuring the world of work as "a privileged means for the full and intense realization of the self" (Gray, 2010, p.714). Gray`s qualitative analysis of a selection of textbooks highlights the high number of work related units featured. For example, New Headway Upper-Intermediate, 2005, contains 12 chapters, 4 of which feature work as a major theme (Gray,2010, p.721). Gray suggests that this illustrates "a 'Brand You' perspective and, in general, a celebratory view of the world of work as a means to personal fulfillment" (2010, p.721).

Lifestyle choices which compliment global economic processes are also depicted in a celebratory fashion by textbooks. Cars are depicted as an essential modern lifestyle choice, and the ability to drive a car is featured in World Link Intro as one of a series of requirements that potential job applicants will need in order to succeed (Stempleski, Douglas \& Morgan, 2004, p.132). Conversely, a reading activity in New Headway Elementary features two people who have never learnt to drive, emphasizing the eccentricity of this oppositional lifestyle choice through the deployment of an explanation mark (Soars\& Soars, 2012, p.110). Mobile phone purchase and usage is similarly promoted and naturalized by textbooks. Headway Upper-Intermediate deploys the phrase "texting to the rescue" (Soars \& Soars, 2005, p.113) whilst English File, Upper Intermediate employs the expression "Saved by her Mobile" (Oxenden \& Latham-Koenig, 2001, p.123), and another exercise uses the phrase "If we had a mobile phone we could call for help" (2001, p.44). The language employed in these various texts helps naturalize the existence of specific commodities and specific economic lifestyle choices as essential, natural and normal.

The type of Western culture found in ELT texts often conforms to an elitist and canonized standard, exemplified by F.R Leavis's The Great Tradition (Leavis, 1950, p.1) in which he identified AngloAmerican writers as the bearers of great and immutable values. Classical writers from the Western literary canon, such as Dickens (Soars\& Soars, 2005, p.29), Charlotte Bronte (Soars\& Soars, 2012, p.47), and W.H. Auden (Soars\& Soars, 2003, p.99), can be discovered in the pages of various Headway textbooks, while English File Upper-Intermediate features reading exercises on Shakespeare (Oxenden \& LathamKoenig, 2001, p.112). Similarly, many ELT reading textbooks focus chiefly on Western literary texts to the exclusion of global literature selections. Of particular note is the reading textbook series Discovering Fiction, which affords space for a large selection of American writers, such as Hemingway, Langston Hughes, Ray Bradbury, and Shirley Jackson (Kay \& Gelshenen, 2001). Yet there is no place for international writers such as Marquez, Mahfouz, or Lao She. English may enjoy the status of a widely used global language, but the previous textbook examples are perhaps symptomatic of the general lack of focus on global culture in many ELT texts.

ELT textbook writers have been criticized for their inherent social and cultural 
biases (Litz, 2002, p.6), whilst ELT materials have been accused of acting as Trojan horses which transmit cultural and economic discourses. This has led to some English teachers feeling concern that, by introducing texts which contain Western culture into an ELT class, they are in some manner contributing to linguistic and cultural imperialism (Sell, 2005, p.86). Other practitioners maintain that all Western culture should be kept out of the ELT classroom (Torikai, 2011) due to its perceived hegemonic properties. Yet keeping students away from Western culture appears impossible in an age when students often choose to gain online and TV access to this culture during their leisure hours. Perhaps, in the long run, teaching the culture found in ELT materials at a deeper, more critical level may instead be more profitable because students require a great deal of cultural education in English classes to achieve a deeper level of communicative competence and fluency (Kramsch, 1993). Such culture, if not explicated properly, can confuse students who may come from very different schematic backgrounds (Widdowson, 1990).This necessitates engaging with foreign cultures and literary texts more rigorously and critically.

\section{Critical thinking approaches in ELT}

Although critical thinking in education was previously thought to be the province of first language education (Fisher, 2001), recent practitioners have begun teaching critical thinking in English foreign language contexts. In Japanese classrooms, several English teachers (Stapleton, 2002; Day, 2003) have observed that their students found little difficulty in thinking critically in English. Promoting a more critical thinking approach could involve practitioners introducing new and different ways of looking at subjects in ELT materials. Byram, Gribkova, \& Starkey (2002) advocate an intercultural approach; deepening the culture found in textbooks by looking at it from different perspectives. For example, the theme of sports can be examined from many critical perspectives, including gender, age, region, religion, and racism (p.22). To aid this process, regularly distributing and recycling discussion vocabulary in ELT classes can help learners understand cultural issues, and find new ways to talk about cultural diversity. Students could be taught words such as 'human rights', 'equality', 'dignity', and 'gender', and this new vocabulary could then be applied to ostensibly superficial textbook topics such as homes, school, work, tourism, and leisure. An individual student response to ELT materials could be encouraged through the introduction of vocabulary such as 'visualize', 'imagine', 'relate', and 'infer'; introducing vocabulary such as 'stereotype', 'racism', 'representation', 'prejudice', 'ethnic minority' and 'bias' could encourage students to evaluate how such ELT materials represent themselves and other cultures through comparison with native cultural items. ELT materials which focus on jobs and working practices could be expanded and deepened through introducing discussion concepts such as 'fair and unfair salaries', 'child labour', 'exploitation', 'permanent' and 'temporary contracts', 'free-trade', and 'sweatshops'. 
This critical approach can be complimented by careful audio-visual selections which suit students' leisure interests. Canning-Wilson's research (2000) revealed student preference for increased use of audio-visual materials in the classroom, whilst other researchers argue that these media can enhance student understanding of culturally specific topics and contexts (Rivers, 1981, p.399). An approach which uses audio-visual materials and vocabulary to critique content and motivate discussion would aim to equip ELT learners with a valuable set of conceptual thinking tools which, it is hoped, would avoid students perceiving foreign culture, or themselves, through the prism of corporate branding and vocational stereotypes.

\section{Teaching English critically in a Japanese university}

This writer undertook the research during the course of the 2012 academic year to attempt to determine the effectiveness of employing vocabulary and visual materials to scaffold students' critical comprehension of textbook content. This research was conducted in a communicative English class at a private university in Japan. The institution assessed and arranged students according to their TOEIC scores, and the 20 students taking this particular course were placed in a middle level class, having achieved a mean class score of 420 on the TOEIC scale. The course was designed around the compulsory class textbook New Cutting Edge Pre-Intermediate (Cunningham, Moor, \& Comyns-Carr, 2005, p.107), a text which integrated all four language skills to aid the completion of speaking and discussion activities. The chapters of the textbook were arranged in terms of theme; topics including leisure, work, fashion, life ambitions, foreign countries, brands, relationships, and money. Each textbook topic was usually divided and taught over two classes; whilst the textbook was used in the first class, the second class saw the teacher introduce vocabulary handouts and audio-visual media, which it was hoped would allow the students to critique the textbook content. In the following paragraphs an example of this approach is given.

The teacher sought to encourage a more critical student approach towards global brands, which was the central topic of Cutting Edge Pre-Intermediate module 12. The chapter, entitled 'Got to have it!', contains a reading exercise focused on the world's most popular brands, such as Coca-Cola, Rolex, Nokia, Mercedes and KFC (2005, p.107). The reading exercise is prefaced with an introductory paragraph which states "Nowadays you have to be a brand". Although the teacher was committed to teaching the vocabulary and grammar within this module, some concern was held regarding the ethics of promoting global brands and products whilst doing so. In the subsequent class, therefore, the teacher sought to engender a more critical approach towards these themes. The students were given handouts with the words 'want' and 'need' written on them, and were encouraged to discuss the differences between them, before brainstorming and listing important things that they really needed in their lives, and things that they merely craved. 
Students were next shown a TGI Fridays advertisement featuring the animated character Homer Simpson (myuserok3, 2008) in which his commercial choices are influenced by his television. The concept of 'brainwashing', or being 'manipulated' by brand advertising was introduced through the distribution of more vocabulary handouts, and students were invited to discuss whether this advertisement targeted the character's practical needs or desires, before discussing whether an advertisement had ever influenced or manipulated them when buying a product. Students were then shown two different examples of Gillette commercials (fishnchimps, 2006; MiscVideos78rpm, 2009) before discussing whether these advertisements employed brainwashing, and targeted one's needs or wants. Students observed that while the older commercial focused purely on the razor's functionality as a shaving device, appealing to a customer's practical needs, the more recent commercial appeared to manipulate its audience through the use of imagery such as fast cars and beautiful women, appealing to customer wants. Finally, students were required to consider if they agreed with the textbooks" "Got to have it!" (Cunningham, Moor \& Comyns-Carr, 2005, p. 107) assertion, whilst also discussing whether the branded goods displayed in the textbook were things that they really needed, or were merely manipulated into wanting.

The focus of the class then shifted from brand advertising to brand ethics; the students were introduced to the concept of exploitation through being shown a CBC news clip about child labor at a Gap clothing factory in India
(Mediascrape, 2007). They were required to listen to the short clip and identify the age of the children, their nationality, and the name of the brand involved in exploiting them. Having been taught the words 'sweatshop', 'exploitation', 'salary', 'working shifts' and 'temperature' the students were then asked to imagine that they were the CEO of a global brand, and decide in pairs how cheaply they would be able to pay their sweatshop workers, what their working shifts would be, and the temperature of the sweatshop factory. A short excerpt was then shown from the documentary The New Rulers of the World (Powertrans, 2012) about global brands in Indonesia. While they listened, the students were required to identify workers' daily salaries (about 1 dollar per day) working shifts (24 hour working shifts), and factory temperature (around 40 degrees Celsius) and then compare this to their own ideas, which were of course much fairer. Finally, the students were required to identify which brands were featured in the documentary. It was discovered that several of these were also featured in the "Got to have it!" section of the course textbook, leading to a final discussion on the merits of brand purchases vs. ethical shopping.

\section{Research methodology and results}

In order to evaluate the general success of this classroom approach towards scaffolding a critical comprehension of culture, some statistical research was undertaken. This research incorporated distributing a small quantitative and qualitative student response questionnaire, which was given to a total of 20 students in the final class of the semester. It was hoped that by 
measuring the students' attitudes towards these classroom media, and comparing their response towards the course textbook, an overall barometer of the effectiveness of the approach could be established. For the 6 quantitative questions, the author decided to employ a Likert-style response option system, a style which commonly contains five response options, but which has also been used with fewer than two and up to seven responses (Dornyei, 2010, p.28). The 6 questions were divided into three sections: course textbook, course videos and vocabulary handouts. A Likert-type scale was designed so that the students would give a clear positive or negative choice from the four choices. The students could therefore answer with a strong or mild positive or negative response. One example question is given below in Table 1.

Table 1: Example close-ended question from the questionnaire

What was your opinion of the course textbook?
a) interesting
b) okay
c) uninteresting
d) boring

In the above example, interesting was assigned a score of 4 points and okay a score of 3 . These were the two 'positive' responses. Uninteresting was given a score of 2 , and boring a score of 1 . These were the two negative responses.
Table 2: Final mean ratings of students' responses towards the course

\begin{tabular}{|c|c|}
\hline Course Materials Questions & Mean \\
\hline 1)
\end{tabular}

1) What was your opinion of the 2.33 course textbook? a) interesting b) okay c) uninteresting d) boring Answer: Okay

2) How did the course textbook help your ability to think critically about foreign culture? a) very useful b) useful c) a little useful d) not useful Answer: Useful.

3) What was your opinion of the video clips used? a) interesting b) okay c) uninteresting d) boring Answer: Interesting.

4) How did the video clips help your ability to think critically about foreign culture? a) very useful b) useful c) a little useful d) not useful Answer: Very useful.

5) What was your opinion of the vocabulary handouts used?a) interesting b) okay c) uninteresting d) boring Answer: Interesting.

6) How did the vocabulary clips help your ability to think critically about foreign culture? a) very useful b) useful c) a little useful d) not useful Answer: Very useful.

2.22

As shown in Table 2(above) the students' overall opinion rating of the textbook was a fairly weak 3.33, whilst its ability to provoke a critical response scored a low 2.22. In comparison, the video clips scored a much higher 3.89 and 3.78 in general ability and critical thinking respectively. The results of the 
questionnaire thus indicate that the textbook was rated less highly than the video materials were. One of the chief reasons for this may lie in Canning-Wilson's (2000) findings which revealed a general student preference for increased use of audiovisual materials in the classroom. Nevertheless, the teacher-created vocabulary handouts also engendered a positive response from students, achieving a general score of 3.34 whilst their ability to provoke a critical response scored a strong 3.56. Question 7, the sole qualitative question, asked the students whether they felt their ability to think more critically about foreign culture had improved or not, and over $80 \%$ of the class replied in the affirmative. When asked to explain why, many of the students wrote that the combination of videos and vocabulary handouts afforded them a wider view of foreign culture than provided by the textbook. Overall, the data was extremely positive, and suggested that students were interested in approaching culture more critically in ELT classes.

\section{Conclusion}

In the modern globalized world, opportunities are increasingly specifiable to English language ability. The ELT industry, whilst profiting from this imbalance, can also be seen to embody a number of economic and cultural discourses, leading some theorists (Phillipson, 1992) to argue that the English language is employed as a tool of hegemony due to the ideology of colonialism that underpins it. This is especially concerning in a classroom context, where students are often mandated textbooks and materials which, as this paper has argued, are inundated with Western specific cultural and commercial references. Nevertheless, Canagarajah (1999 as cited in Gray, 2010) suggests that students do on occasions recognise the ideological nature of certain content, and seek to challenge it (p.730). Diaspora can also occur, where local communities creatively re-embed foreign culture within their own local contexts (Osgerby, 2004, p.172). Thus, Gray observes that "clearly there is a need for more detailed research into how such content is perceived" (p.730). In the meantime, while ELT practitioners in the field may have little choice over the types of materials that they use (Flavell, 1994), a culturally critical approach to such materials can be introduced at a simplified, basic level through the introduction of scaffolded vocabulary, discussion questions, and discrete use of audio visual materials. Therein lies a collective challenge for ELT institutions and teachers: to inculcate a more critical response to materials used in their classrooms whilst fulfilling their language teaching objectives. 


\section{About the author}

Neil Addison was born in the UK and is a university lecturer in the Kanto region of Japan. He has published in various Japanese journals on teaching literature, and is currently undertaking his PhD in linguistics at Birmingham University. His areas of interest include literature in language teaching and critical pedagogy.

\section{References}

Bello, W. (2001). Structural adjustment programmes. In E. Goldsmith, J. Mander (eds.). The case against the global economy $\mathcal{E}$ for a turn towards localization. (pp. 127134). London, England: Earthscan Publications.

Brumfit, C. (2001). Individual freedom in language teaching. Oxford, England: Oxford University Press.

Byram, M., Gribkova, B., \& Starkey, H. (2002). Developing the intercultural dimension in language teaching: A practical introduction for teachers. The Council of Europe. Retrieved 22/12/2012 from: http://www.coe.int/t/dg4/linguistic/ Source/Guide_dimintercult_EN.pdf

Canagarajah, A. S. (1999). Resisting linguistic imperialism in English teaching. Oxford, England: Oxford University Press.

Canning-Wilson, C. (2000). Practical aspects of using video in the foreign language classroom. The Internet TESL Journal. Vol.VI, No.11, 2000. Retrieved 06/1/ 2012 from: http://itselj.org/Articles/ Canning-Video.html.

Coulmas, F. (1992). Language and economy. Oxford, England: Blackwell Publishers.

Cunningham, S., Moor, P., \& Comyns Carr, J. (2004). Cutting edge pre-intermediate students' book. Essex, England: Pearson Longman.

Day, R. (2003). Teaching critical thinking and discussion. The Language Teacher.27(7).

Dornyei, Z. (2010). Questionnaires in second language research. New York, NY: Routledge.

ETS. (2013). Who we are. Retrieved 18/09/ 2013 from: https://www.ets.org/ about/who

Fisher, A. (2001). Critical thinking: An introduction. Cambridge, England: Cambridge University Press.

Fishnchimps. (2006). Gillette M3 ad [YouTube]. Retrieved 15/03/2010 from: http: / / www.youtube.com / watch? $\mathrm{v}=6 \mathrm{D} 5$ J J943vOI.

Flavell, R. H. (Ed.) (1994). ELT policy and its impact: A case study. London, England: Modern English Publications in association with The British Council.

Goldsmith, E. (2001). Development as colonization. In E. Goldsmith, J. Mander (eds.), The case against the global economy $\mathcal{E}$ for a turn towards localization. (pp.1934). London, England: Earthscan Publications.

Gray, J. (2010). The branding of English and the culture of the new capitalism: Representations of the world of work in English language textbooks. Applied Linguistics: 31(5), 714-733.

Griffith, S. (1999). Teaching English abroad: talk your way around the world (4th ed). Oxford, UK: Vacation Work.

Howatt, A.P.R., \& Widdowson, H. (2004). A history of English language teaching. Oxford, England: Oxford University Press.

Kay, J., \& Gelshenen, R. (2001). Discovering fiction: A reader of American short stories, student's book 2(2nd ed.). Cambridge, England: Cambridge University Press. 
Kim, D. (2012, April 29). Tests that make money. The Korea Times. Retrieved 31/ 09/2012 from: http:// www.koreatimes.co.kr/www/news/ biz/2012/10/328_109920.html

Kramsch, C. (1993). Context and culture in language teaching (6th ed.). Oxford, England: Oxford University Press.

Leavis, F.R. (1950). The great tradition (2nd ed.). New York, NY: George W. Stewart Publisher Inc.

Litz, D.R.A. (2005). Textbook evaluation and ELT management: A South Korean case study. Asian EFL Journal. Retrieved 22/ 02/2013 from: http:/ / www.asian-efljournal.com/Litz_thesis.pdf

Mar-Molinero, C. (2006). The European linguistic legacy in a global era: Linguistic imperialism, Spanish and the Instituto Cervantes. In Mar-Molinero, C., Stevenson, P. (eds.). Language ideologies, politics and practices: Language and the future of Europe. (pp.76-88). Basingstoke, U.K: Palgrave, Macmillan.

Mediascrape. (2007). Sweatshop raided again [You-tube]. Retrieved 11/02/2012 from:http:/ / www.youtube.com/ watch?v=A0F_mdRE7tM

MiscVideos78rpm. (2009). Super speed razor commercial (1956) [You-Tube]. Retrieved 15/03/2010 from: http:// w w w. y o t u b e.co m/ watch?v=dMvUhJZtnjg

myuserok3. (2008). The Simpsons - commercial - T.G.I. Fridays - Homer Simpson [YouTube].Retrieved 02/03/2010 from: http: / / w w w y outube.com / watch? $\mathrm{v}=\mathrm{zcZkDC} 4 \mathrm{f} 6$ to.

Oh, Y., \& Kang, S. (2009, January 1). Korea to replace TOEFL with state tests. Korea Times, retrieved 31/09/2012 from http:/ /www.koreatimes.co.kr/www/news/ nation/2011/04/117_54652.html
Osgerby, B. (2004). Youth media. New York, NY: Routledge.

Oxenden, C., \& Latham-Koenig, C. (2001). English file, upper intermediate students' book, Oxford, England: Oxford University Press.

Parliament. UK. (2001, July 9). The Minister for Europe (Peter Hain). Originally retrieved 14/09/2011 from: http:// www.publications.parliament.uk/pa/ cm200102/cmhansrd/vo010709/ debtext/10709-30.htm

Phillipson, R. (1992). Linguistic imperialism. Oxford, England: Oxford University Press.

Pilger, J. (1999). Hidden agendas, London, UK: Vintage Press.

Powertrans. (2012). John Pilger-The new rulers of the world [You-Tube]. Retrieved 21/ 08/2012 from: http:// w w w . y o u t u b e.co m / watch?v=pfrL2DUtmXY

Rivers, W.M. (1981). Teaching foreign language skills (2nd ed.). Chicago, USA: The University of Chicago Press.

Sell, J.P. (2005). 'Why teach literature in the foreign language classroom?' Encuentro, $15,86-93$

Soars, J., \& Soars, L. (2003). New Headway intermediate students' book. Oxford, England: Oxford University Press.

Soars, J., \& Soars, L. (2005). Headway upperintermediate students' book. Oxford, England: Oxford University Press.

Soars, J., \& Soars, L. (2012). New Headway elementary students book (3rd ed.).Oxford, England: Oxford University Press.

Stapleton, P. (2002). Critical thinking in Japanese L2 writing: Rethinking tired constructs. ELT Journal, 56(3), 250-257.

Stempleski, S., Douglas, N., \& Morgan, J.R. (2004).World Link intro: Developing 
English fluency. Boston, USA: Thomson, Heinle.

Tollefson, J.W. (1991). Planning language, planning inequality: Language policy in the community. London, England: Longman/Pearson Education.

Torikai, K. (2011). Point of view/Kumiko Torikai: Japan needs new paradigm of English education. Retrieved from: http:/ / englipedia.informe.com/ forum/in-the-news-f14/japan-needsnew-paradigm-of-english-educationt2172.html

Widdowson, H. (1990). Aspects of language teaching. Oxford, England: Oxford University Press.

\section{Student Course Questionnaire}

1) What was your opinion of the course textbook?
a) interesting
b)okay
c) uninteresting
d) boring
Please circle $a, b, c$ or $d$.

2) How did the course textbook help your ability to think critically about foreign culture?
a) very useful
b) useful
c) a little useful
d) not useful

3) What was your opinion of the video clips used?
a) interesting
b) okay
c) uninteresting
d) boring

4) How did the video clips help your ability to think critically about foreign culture?
a) very useful
b) useful
c) a little useful
d) not useful

5) What was your opinion of the vocabulary handouts used?
a) interesting
b) okay
c) uninteresting
d) boring

6) How did the vocabulary handouts help your ability to think critically about foreign culture?
a) very useful
b) useful
c) a little useful
d) not useful

7) My ability to think more critically about foreign culture has improved/ not improved.

Please circle improved or not improved, and if possible explain why below. 